\title{
Treatment of Idiopathic Immune Mediated Hemolytic Anaemia in Dogs
}

\author{
Chopel G. Lachungpa ${ }^{1}$, D. Chandrasekaran ${ }^{2 *}$, M.B. Thilagar ${ }^{3}$ and T.M.A. Senthil Kumar ${ }^{4}$ \\ ${ }^{1}$ Department of Veterinary Clinical Medicine, Madras Veterinary College, Tamil Nadu Veterinary and Animal Sciences \\ University, Chennai, Tamil Nadu, INDIA \\ ${ }^{2}$ Department of Clinics, Madras Veterinary College, Tamil Nadu Veterinary and Animal Sciences University, Chennai, \\ Tamil Nadu, INDIA \\ ${ }^{3}$ Department of Veterinary Clinical Medicine, Madras Veterinary College, Tamil Nadu Veterinary and Animal Sciences \\ University, Chennai, Tamil Nadu, INDIA \\ ${ }^{4}$ Department of Animal Biotechnology, Madras Veterinary College, Tamil Nadu Veterinary and Animal Sciences University, \\ Chennai, Tamil Nadu, INDIA \\ *Corresponding author: D Chandrasekaran; E-mail:drchandrus73@gmail.com
}

Received: 18 Mar., 2020

Revised: 20 April, 2020

Accepted: 22 April, 2020

\begin{abstract}
Immune-mediated hemolytic anemia (IMHA) is the most common autoimmune disease in dogs. This study was conducted to evaluate prednisolone and azathioprine therapeutic protocols for the management of idiopathic IMHA in dogs. The anaemic dogs brought with clinical signs such as pale or icteric mucous membranes were screened for IMHA by saline agglutination and spherocyte count and confirmed by flow cytometry. The positive cases were further subjected to haematology, biochemistry, coagulation profile, MAT and polymerase chain reaction (PCR) for the diagnosis of underlying secondary causes like Babesia spp, Ehrlichia canis and Leptospira spp (secondary IMHA). Thirty two cases were positive for IMHA, out of which thirteen cases were primary (Idiopathic) IMHA (17.3\%) and remaining nineteen cases were secondary IMHA $(82.7 \%)$ due to underlying causes such as Babesia gibsoni (13), Ehrlichia canis (3) and Leptospira spp. (3) respectively. Immunosuppressive therapy with prednisolone and prednisolone in combination with azathioprine and specific therapy of etiological agent with supportive therapy was used. Significant increase in Hb, PCV, RBC and thrombocyte count, significant decrease in leucocyte, neutrophil, monocyte and total protein and significant increase in ALT activity was recorded after therapy. Prednisolone was found to be effective in the management of canine IMHA than prednisolone combined with azathioprine.
\end{abstract}

Keywords: Dog, Idiopathic IMHA, Treatment, Prednisolone, Azathioprine

IMHA is one of the common types of anemia in small animals and considered to be the most common autoimmune disease in dogs. The disease is caused by immune-mediated destruction following activation of complement and/or extravascular haemolysis of red blood cells (RBCs) and results in an accelerated decrease in the total RBC mass (Mitchell and Kruth, 2010). Immunemediated haemolytic anaemia (IMHA) was a common haematological disorder in dogs (Fenty et al., 2011) with major therapeutic challenges related to complications and high mortality rates (Swann and Skelly, 2013). Idiopathic/ primary IMHA was immune mediated destruction of RBCs resulting in loss of self tolerance against endogenous (self) antigens and not associated with any cause, where if the immune reaction was associated with an exciting cause/ foreign (non self) antigen such as infectious disease, chronic inflammation, neoplasia, toxins, parasites, drugs, vaccines, the condition was termed as secondary IMHA (Balch and Mackin, 2007; Jutkowitz et al., 2013).

Balch and Mackin (2007) reported that physical examination typically revealed pale mucous membranes,

How to cite this article: Lachungpa, C.G., Chandrasekaran, D., Thilagar M.B. and Kumar, T.M.A.S. (2020). Treatment of idiopathic immune mediated hemolytic anaemia in dogs. J. Anim. Res., 10(3): 433-440.

Source of Support: None; Conflict of Interest: None क्) 
tachypnea, splenomegaly, hepatomegaly, icterus, pigmenturia (hemoglobinuria or bilirubinuria), fever, and lymphadenopathy and jaundice were most easily observed abnormalities in IMHA. Jutkowitz et al. (2013) stated that the signs presented by IMHA dogs were acute or chronic and most common signs in chronic form were lethargy, weakness, inappetance, vomiting, diarrhea and pigmenturia. Acute form characterized by sudden collapse.

The diagnosis of IMHA is based on the presence of anemia and a combination of clinical pathology findings which can include the presence of spherocytes (Weinkle et al., 2005), autoagglutination of erythrocytes resulting from anti-erythrocyte $\operatorname{IgG}$ and $\operatorname{IgM}$ and/or a positive Coomb's test which detects antibodies or complement on the erythrocyte surface. Flow cytometry for the detection of $\mathrm{IgG}$ on $\mathrm{RBC}$ has been proven to be highly sensitive and specific for the diagnosis of IMHA (Morley et al., 2008).

Weinkle et al. (2005) reported that the goal of treatment was stabilization of the packed cell volume (PCV) and resolution of anemia. Despite the apparently straight forward recommendation, treatment success ranges from 40 to 70 per cent with frequent relapses. There was no consensus on the duration of time over which dogs should receive treatment, on the way in which the dose should be tapered over time, or on the appropriate response to relapses reported by Swann and Skelly (2013).

Mortality rates for idiopathic IMHA range from 22 to 80 per cent, with significantly increased mortality early in the disease course (Whelan et al., 2009; Ishihara et al., 2010; Mellett et al., 2011; Swann and Skelly, 2011).

Jutkowitz et al. (2013) reported that prednisolone at $2 \mathrm{mg} /$ $\mathrm{kg}$ / day is the main treatment for IMHA. Whitney and Day (2011) stated that azathioprine used in combination with glucocorticosteroids to obtain glucorticosteroid sparing effect i.e to help in rapid tapering of steroids. Hence, the present study was undertaken with the objective to evaluate prednisolone and azathioprine therapeutic protocols for the management of idiopathic IMHA in dogs.

\section{MATERIALS AND METHODS}

Seventy five anemic dogs were presented to the Small Animals Out Patient Unit of Madras Veterinary teaching Hospital and Critical Care Unit of the Department of Veterinary Clinical Medicine, Madras Veterinary College,
Chennai during a period of 1 year from July 2016 to June 2017. An individual history of those dogs with pale or icteric mucous membranes were initially evaluated for saline agglutination, sphereocytosis, complete blood count, serum biochemistry and confirmed by flow cytometry.

Thirty-two dogs positive by flow cytometry were selected for the study. The saline agglutination test was performed by mixing a drop of whole blood collected in EDTA vacutainer with drop of saline on a glass slide. Microscopic agglutination test was performed with a saline dilution on a glass slide (one drop of blood to two drops of saline) and inspected under light microscope. The positive result was manifested by clumping of red blood cells (Balch and Mackin, 2007). An air dried thin blood smear was made from capillary blood obtained from the anterior edge of the hairless ventral surface of the ear, stained with Leishman-Giemsa stain and examined microscopically for Babesia species and Ehrlichia canis organism, differential leucocyte count, spherocyte count and blood picture analysis.

\section{Flow cytometer}

Whole blood samples were analyzed by a flow cytometer as per the procedure of Kucinskiene et al. (2005). The IMHA flurochrome stained RBCs were acquired using MoFlow XDP flow cytometery (Beckman Coulter, USA) and data were analyzed using the summit software.

\section{Multiplex PCR}

DNA isolation kit (QIAamp DNA Mini Kit ${ }^{\circledR}$, Qiagen) was used for the extraction of parasite DNA from $200 \mu \mathrm{l}$ of blood collected in EDTA vacutainers according to the manufacturer's instructions. Genomic DNA isolated from the whole blood of healthy dog was used as a negative control.

Multiplex PCR for the amplification of the 16s rRNA gene fragment of molecular length $619 \mathrm{bp}$ in genus Babesia and VirB9 of E. canis with a molecular length $380 \mathrm{bp}$ was employed following the procedure of Kledmanee et al. (2009). Nested PCR for the amplification of the 16s rRNA gene fragment of $E$. canis was employed following the procedure of Rajagopal et al. (2009). Thermocycling consisted of initial denaturation step of $15 \mathrm{~min}$ at $94^{\circ} \mathrm{C}$ followed by 30 cycles of $45 \mathrm{sec}$ at $94^{\circ} \mathrm{C}, 45 \mathrm{sec}$ at $65^{\circ} \mathrm{C}$, 
and $90 \mathrm{sec}$ at $72^{\circ} \mathrm{C}$ with a final extension step of $10 \mathrm{~min}$ at $72^{\circ} \mathrm{C}$. The amplicons were separated by electrophoresis in $1.5 \%$ agarose gel in $40 \mathrm{mM}$ Tris-acetic acetate of $\mathrm{pH} 8.4$, $1 \mathrm{mM}$ EDTA, stained with ethidium bromide $(0.5 \mu \mathrm{g} / \mathrm{ml})$ and visualized under UV light.

\section{Microscopic agglutination test (MAT)}

A battery of live leptospira serovars (L. australis, $L$. autumnalis, L. ballum, L. bataviae, L. canicola, $L$. grippotyphosa, L. hebdomadis, L. icterohaemorrhagiae, L. javanica, L. pomona and L. pyrogenes) were employed. The antigen antibody reaction / agglutination observed at $>1$ : 200 serum dilutions were considered positive.

Positive samples for hemoprotozoan parasite like Babesia spp and Ehrlichia spp screened by multiplex PCR and leptospirosis by MAT were excluded from study. The results are expressed as mean \pm SE. Data are classified with descriptive statistics and $\mathrm{P}$ values $<0.05$ are considered statistically significant. Data analysis was performed with the SPSS 20.

Two groups viz. I and II were formed with each group comprising of 7 and 6 dogs of different breed, either sex and varying age respectively. The dogs affected with primary or idiopathic IMHA were randomly selected and included under treatment trial.

\section{Group I - Prednisolone $(\mathrm{n}=6)$}

$\square \quad$ Prednisolone (Wysolone, Wyeth Ltd., 5mg and 10mg)@2 mg / kg body weight per os. BID for 7 days followed by $1 \mathrm{mg} / \mathrm{kg}$ body weight per os. BID for next 7 days. The drug was tapered to $0.5 \mathrm{mg} / \mathrm{kg}$ body weight per os. BID for 7 days and $0.25 \mathrm{mg} / \mathrm{kg}$ body weight per os. BID for subsequent 7 days as per McCullough (2003).

Group II - Prednisolone + Azathioprine $(n=7)$

Azathioprine (Imuran, GSK pharmaceuticals Ltd., $50 \mathrm{mg}$ and $100 \mathrm{mg}$ ) @ $1 \mathrm{mg} / \mathrm{kg}$ body weight per os. BID for first week followed by $0.5 \mathrm{mg} /$ $\mathrm{kg}$ body weight per os. BID for next 7 days. The drug was tapered to $0.25 \mathrm{mg} / \mathrm{kg}$ body weight per os. BID for another one week and $0.25 \mathrm{mg} / \mathrm{kg}$ body weight per os. SID for next one week as per McCullough (2003).

$\square$ Prednisolone at the rate of $1 \mathrm{mg} / \mathrm{kg}$ body weight
$\mathrm{I} / \mathrm{M}$ or per os. BID for 7 days followed by $0.5 \mathrm{mg}$ / kg body weight per os. BID for 7 days. The drug was tapered to $0.25 \mathrm{mg} / \mathrm{kg}$ body weight per os. BID for another one week and $0.25 \mathrm{mg} / \mathrm{kg}$ body weight per os. SID for next one week.

\section{RESULTS AND DISCUSSION}

Haematological, biochemical and coagulation parameters were recorded before treatment $(0$ day $)$ and after treatment viz., $14^{\text {th }}$ day and $28^{\text {th }}$ day idiopathic IMHA. The quantitative data were subjected to One-Way Annova and independent sample t-test. In thirteen primary IMHA dogs, six dogs received immunosuppressive dose of prednisolone (P Protocol) and seven dogs received prednisolone combined with azathioprine (AP Protocol).

Dogs that were treated with prednisolone showed apparent clinical recovery on day $14^{\text {th }}$ and $28^{\text {th }}$ day after initiation of treatment. In all the dogs which survived, there was a significant increase in the means of $\mathrm{Hb}, \mathrm{RBC}, \mathrm{PCV}$ and platelets and decrease in mean WBC, PT and APTT. But there was no significant difference in means of $\mathrm{MVC}$, $\mathrm{MCHC}, \mathrm{MCH}$, neutrophil, lymphocyte, monocyte, and eosinophil (Table 1 and 2).

In prednisolone treatment group there was significant increase in the means of $\mathrm{Hb}, \mathrm{RBC}, \mathrm{PCV}$, platelets and significant decrease in means of WBC, PT, APTT, BUN and Total Bilirubin levels (Table 1, 2, 3). Similar increase was recorded by Mason et al. (2003) by using prednisolone. The improvement might be due to reduced erythrophagocytosis of opsonized RBC (Piek, 2011) or decreased production of antibodies (Barker et al., 1992) by reducing lymphocytes in the circulation pool (Dowling, 1995). These drugs reduce the phagocytic action of macrophages by reducing the expression of surface receptors which detect immunoglobulin on $\mathrm{RBC}$ and also they stabilize the lysosomal membrane of macrophages, decrease complement activation, block chemotaxis and prevent synthesis of prostaglandin and leukotriene (Dowling, 1995). Both extravascular and intravascular destruction of erythrocytes are affected by prednisolone. On $28^{\text {th }}$ day $\mathrm{MCV}, \mathrm{MCHC}$ and $\mathrm{MCH}$ were within normal range, but $\mathrm{RDW}$ was higher. A state of regenerative anaemia was present even after therapy, but MCV was less sensitive than RDW in detecting regenerative anaemia (Hodges and Christopher, 2011). 
Table 1: Effect of different treatments on haemogram in idiopathic IMHA

\begin{tabular}{|c|c|c|c|c|c|c|c|c|}
\hline \multirow{2}{*}{ Parameters } & \multicolumn{4}{|c|}{ Prednisolone $(n=6)$} & \multicolumn{4}{|c|}{ Prednisolone +Azathioprine $(n=7)$} \\
\hline & Day 0 & $14^{\text {th }}$ day & $28^{\text {th }}$ day & F-Value & Day 0 & $14^{\text {th }}$ day & $28^{\text {th }}$ day & F-Value \\
\hline $\mathrm{Hb}(\mathrm{g} / \mathrm{dL})$ & $4.17 \pm 0.54^{\mathrm{a}}$ & $7.50 \pm 0.56^{\mathrm{b}}$ & $10.50 \pm 0.28^{c}$ & $33.17 * *$ & $5 \pm 0.53^{\mathrm{a}}$ & $6.71 \pm 0.52^{\mathrm{b}}$ & $9.17 \pm 0.40^{\mathrm{c}}$ & $16.98 * *$ \\
\hline $\mathrm{RBC}(\mathrm{mill} / \mu \mathrm{L})$ & $4.00 \pm 0.68^{\mathrm{a}}$ & $4.89 \pm 0.68^{\mathrm{a}}$ & $5.1 \pm 0.64^{b}$ & $7.52 * *$ & $2.71 \pm 0.42^{\mathrm{a}}$ & $3.86 \pm 0.59^{\mathrm{ab}}$ & $5.00 \pm 0.85^{\mathrm{a} b}$ & $5.80^{* *}$ \\
\hline PCV $(\%)$ & $12.67 \pm 1.4^{\mathrm{a}}$ & $21.33 \pm 3.04^{b}$ & $30.25 \pm 2.25^{\mathrm{c}}$ & $12.30 * *$ & $13.53 \pm 1.73^{\mathrm{a}}$ & $21.43 \pm 2.61^{b}$ & $27.50 \pm 3.11^{\mathrm{c}}$ & $13.33 * *$ \\
\hline MCV (fL) & $61.17 \pm 5.12$ & $58.0 \pm 3.83$ & $58.75 \pm 5.10$ & $0.13^{\mathrm{NS}}$ & $53.43 \pm 6.70$ & $57.43 \pm 6.3$ & $56.33 \pm 4.92$ & $0.10^{\mathrm{NS}}$ \\
\hline $\mathrm{MCHC}(\mathrm{g} / \mathrm{dL})$ & $38.67 \pm 3.92$ & $35.34 \pm 3.12$ & $35.23 \pm 0.36$ & $1.17^{\mathrm{NS}}$ & $37.29 \pm 2.91$ & $33.29 \pm 3.02$ & $36.17 \pm 4.61$ & $1.15^{\mathrm{NS}}$ \\
\hline $\mathrm{MCH}(\mathrm{pg})$ & $19.67 \pm 1.08$ & $22.50 \pm 3.43$ & $20.75 \pm 2.75$ & $0.33 \mathrm{NS}$ & $19.57 \pm 2.23$ & $18.86 \pm 2.2$ & $20.67 \pm 3.77$ & $0.22 \mathrm{NS}$ \\
\hline
\end{tabular}

Mean bearing same manuscript in the row do not differ significantly

** - Statistically highly significant $(\mathrm{P} \leq 0.01) *$ - Statistically significant $(\mathrm{P}>0.05){ }^{\mathrm{NS}}$ - Non significant

Table 2: Effect of different treatments on leucogram and coagulation profile in idiopathic IMHA

\begin{tabular}{|c|c|c|c|c|c|c|c|c|}
\hline \multirow{2}{*}{ Parameters } & \multicolumn{4}{|c|}{ Prednisolone $(n=6)$} & \multicolumn{4}{|c|}{ Prednisolone + Azathioprine $(n=7)$} \\
\hline & Day 0 & $14^{\text {th }}$ day & $28^{\text {th }}$ day & F-Value & Day 0 & $14^{\text {th }}$ day & $28^{\text {th }}$ day & F-Value \\
\hline $\mathrm{WBC}(/ \mu \mathrm{L})$ & $\begin{array}{l}26700.00 \pm \\
3846.64^{\mathrm{a}}\end{array}$ & $\begin{array}{l}15416.67 \pm \\
2805.99^{b}\end{array}$ & $\begin{array}{l}13150.00 \pm \\
850^{\mathrm{b}}\end{array}$ & $5.37 *$ & $\begin{array}{l}28371.73 \pm \\
3728.25^{\mathrm{a}}\end{array}$ & $\begin{array}{l}15314.29 \pm \\
685.71^{b}\end{array}$ & $\begin{array}{l}13333.34 \pm \\
494.41^{b}\end{array}$ & $11.65 * *$ \\
\hline Neutrophil (\%) & $81.17 \pm 2.37$ & $74.67 \pm 2.02$ & $76.25 \pm 3.01$ & $8.25 \mathrm{NS}$ & $82.71 \pm 1.44$ & $74.57 \pm 0.71$ & $76.17 \pm 1.51$ & $18.79 * *$ \\
\hline Lymphocyte (\%) & $16.33 \pm 1.92$ & $16.50 \pm 1.28$ & $15 \pm 2.12$ & $0.85 \mathrm{NS}$ & $14.57 \pm 1.74$ & $18.71 \pm 1.45$ & $16.0 \pm 1.61$ & $1.66^{\mathrm{NS}}$ \\
\hline Monocyte (\%) & $5.33 \pm 0.95$ & $5.67 \pm 0.95$ & $4.50 \pm 0.8$ & $0.34^{\mathrm{NS}}$ & $3.43 \pm 0.29$ & $4.29 \pm 0.36$ & $3.83 \pm 0.30$ & $1.90^{\mathrm{NS}}$ \\
\hline Eosinophil (\%) & $1.25 \pm 0.25$ & $1.33 \pm 0.33$ & $1 \pm 00$ & $0.29 \mathrm{NS}$ & $1.83 \pm 0.40$ & $1.0 \pm 0.36$ & $0.6 \pm 0.40$ & $0.25^{\mathrm{NS}}$ \\
\hline $\begin{array}{c}\text { Platelet } \\
\left(10^{3} / \mathrm{cmm}\right)\end{array}$ & $\begin{array}{l}80666.67 \pm \\
15204.53^{\mathrm{a}}\end{array}$ & $\begin{array}{l}147500 \pm \\
17387^{\mathrm{a} b}\end{array}$ & $\begin{array}{l}216500 \pm \\
40152^{b}\end{array}$ & $0.94 * *$ & $\begin{array}{l}77095.43 \pm \\
19023.23^{a}\end{array}$ & $\begin{array}{l}154000 \pm \\
20311.85^{b}\end{array}$ & $\begin{array}{l}231833.34 \pm \\
31246.77^{b}\end{array}$ & $8.60 * *$ \\
\hline PT (sec) & $51.50 \pm 11.10^{\mathrm{a}}$ & $31.83 \pm 6.11^{\mathrm{ab}}$ & $15.75 \pm 5.57^{b}$ & $3.94 *$ & $39.57 \pm 10.77$ & $27.71 \pm 9.33$ & $17.67 \pm 4.09$ & $1.70^{\mathrm{NS}}$ \\
\hline APTT(sec) & $61.50 \pm 9.06^{\mathrm{a}}$ & $40.40 \pm 8.06^{\mathrm{ab}}$ & $22.75 \pm 7.43^{b}$ & $5.08 *$ & $61.57 \pm 13.31$ & $49.29 \pm 11.43$ & $33.67 \pm 12.91$ & $3.04 \mathrm{NS}$ \\
\hline
\end{tabular}

Mean bearing same manuscript in the row do not differ significantly.

** - Statistically highly significant $(\mathrm{P} \leq 0.01) *$ - Statistically significant $(\mathrm{P}>0.05){ }^{\mathrm{NS}}$ - non significant.

Table 3: Effect of different treatments on serum biochemistry in idiopathic IMHA

\begin{tabular}{|c|c|c|c|c|c|c|c|c|}
\hline \multirow{2}{*}{ Parameters } & \multicolumn{4}{|c|}{ Prednisolone $(n=6)$} & \multicolumn{4}{|c|}{ Prednisolone + Azathioprine $(n=7)$} \\
\hline & Day 0 & $14^{\text {th }}$ day & $28^{\text {th }}$ day & F-Value & Day 0 & $14^{\text {th }}$ day & $28^{\text {th }}$ day & F-Value \\
\hline BUN (mg/dL) & $57.12 \pm 2.21^{\mathrm{a}}$ & $39.01 \pm 1.4^{b}$ & $24.36 \pm 1.5^{\mathrm{c}}$ & $80^{* *}$ & $54.12 \pm 3.9$ & $32.98 \pm 2.15$ & $26.87 \pm 2.31$ & $30.62^{* *}$ \\
\hline $\mathrm{Cr}(\mathrm{mg} / \mathrm{dL})$ & $2 \pm 0.36$ & $1.80 \pm 0.80$ & $0.75 \pm 0.25$ & $1.38 \mathrm{NS}$ & $1.25 \pm 0.27$ & $1.14 \pm 0.26$ & $0.83 \pm 0.16$ & $0.74 \mathrm{NS}$ \\
\hline $\mathrm{TP}(\mathrm{g} / \mathrm{dL})$ & $6.33 \pm 0.33$ & $6.80 \pm 0.55$ & $6.25 \pm 0.25$ & $0.99 \mathrm{NS}$ & $6.08 \pm 0.53$ & $6.0 \pm 0.37$ & $6.00 \pm 0.36$ & $0.04 \mathrm{NS}$ \\
\hline Albumin (g/dL) & $2.33 \pm 0.0 .21$ & $2.2 \pm 0.2$ & $2.25 \pm 0.25$ & $0.10^{\mathrm{NS}}$ & $2.40 \pm 0.21$ & $2.43 \pm 0.20$ & $2.33 \pm 0.33$ & $0.04 \mathrm{NS}$ \\
\hline Globulin (g/dL) & $4.00 \pm 0$ & $4.53 \pm 0.49$ & $3.75 \pm 0.25$ & $1.05 \mathrm{NS}$ & $3.65 \pm 0.40$ & $3.65 \pm 0.41$ & $3.81 \pm 0.45$ & $0.15^{\mathrm{NS}}$ \\
\hline Albumin:Globulin & $0.3 \pm 0.16$ & $0.6 \pm 0.24$ & $0.75 \pm 0.25$ & $0.32 \mathrm{NS}$ & $0.86 \pm 0.14$ & $0.86 \pm 0.14$ & $0.83 \pm 0.16$ & $0.038^{\mathrm{NS}}$ \\
\hline ALT (IU/L) & $115.00 \pm 29.89$ & $116.4 \pm 39.98$ & $99.75 \pm 42.75$ & $0.55 \mathrm{NS}$ & $112.71 \pm 5.41^{\mathrm{a}}$ & $189.14 \pm 17.5^{b}$ & $224.67 \pm 34.52^{\mathrm{c}}$ & $7.47^{* *}$ \\
\hline ALP (IU/L) & $431.17 \pm 151.34$ & $216.00 \pm 56.33$ & $380.50 \pm 173.18$ & $0.71 \mathrm{NS}$ & $202.14 \pm 70.0^{\mathrm{a}}$ & $390.57 \pm 64.0^{b}$ & $688.87 \pm 36.40^{\mathrm{c}}$ & $27.81 * *$ \\
\hline T.bilirubin (IU/L) & $1.82 \pm 0.30^{\mathrm{a}}$ & $0.93 \pm 0.09^{\mathrm{b}}$ & $0.74 \pm 0.25^{b}$ & $16^{* *}$ & $1.26 \pm 0.41$ & $1.57 \pm 0.29$ & $1.17 \pm 0.40$ & $0.52 \mathrm{NS}$ \\
\hline D.bilirubin (IU/L) & $1.8 \pm 0.58$ & $0.44 \pm 0.13$ & $0.75 \pm 0.25$ & $1.95 \mathrm{NS}$ & $1.12 \pm 0.39$ & $1.860 \pm 0.34$ & $1.33 \pm 0.42$ & $1.6^{\mathrm{NS}}$ \\
\hline
\end{tabular}

Mean bearing same manuscript in the row do not differ significantly.

** - Statistically highly significant $(\mathrm{P} \leq 0.01) *$ - Statistically significant $(\mathrm{P}>0.05)^{\mathrm{NS}}$ - Non significant. 
The first indication of this response is stabilization of the hematocrit, followed by a slow increase to normal values over several weeks (Day, 1996). Other indications of a good response to corticosteroids include the resolution of autoagglutination, an increase in reticulocyte count (if the anemia was initially non responsive) and decreased numbers of spherocytes on the blood smear. In the first few days of treatment, an increase in spherocytes may be observed because the mononuclear system is removing fewer antibody-coated RBCs.

In the present study there was significant decrease in leukocyte, lymphocyte, monocyte and granulocyte counts after the therapy. Similar response was recorded by Brunton et al. (2005), which might be due to redistribution of cells from peripheral circulation. Glucocorticoids reduce lymphocyte number by redistributing T-lymphocyte in circulatory pool. Thus few T-lymphocytes are exposed to antigen, which in turn decreases activation and division of these cells. Thereby affecting the counts and antibody production, as few cells are available for antibody production (Dowling, 1995). Glucocorticoids have an anti-inflammatory effect. They reduce the release of pro-inflammatory cytokines (interlukines, $\mathrm{TNF} \alpha$ etc.) and reduce the activity of neutrophils and T-helper cells (Rang et al., 2007). Similar effect might be the reason for reduction in leukocyte counts in the present study. There was no significant difference in ALP and ALT activity levels after immunosuppressive therapy, the values were remain high.

Means of Blood urea nitrogen (BUN) and total bilirubin were significantly reduced on $14^{\text {th }}$ and $28^{\text {th }}$ day after treatment with prednisolone. However, there was no significant difference in means of creatinine, total protein, albumin, globulin, A: G ratio, ALP, ALT, direct bilirubin and total bilirubin as shown in Table-3. Out of six dogs receive treatment, four dogs recovered after 28 days of therapy. One dog died on $2^{\text {nd }}$ week of treatment whereas other one died on $9^{\text {th }}$ day of treatment.

There was also significant increase in the means of $\mathrm{Hb}, \mathrm{RBC}$ and PCV and platelet for dogs treated with prednisolone and azathioprine combination on $14^{\text {th }}$ and $28^{\text {th }}$ day after initiation of treatment. There was a significant reduction in mean of WBC and neutrophil. But there was no significant difference in means of MCV, MCHC, MCH, lymphocyte, monocyte, and eosinophil, PT and APTT as shown in Table 1 and Table 2.
BUN significantly reduced on $14^{\text {th }}$ and $28^{\text {th }}$ day after treatment with prednisolone and azathioprine combination. There was highly significant increase in mean activity levels of ALP, ALT and Glucose but there was no significance in means of direct bilirubin, total bilirubin, creatinine, total protein, albumin, globulin and A:G ratio (Table 3). Out of seven dogs received treatment, four dogs recovered after 28 days of therapy. Two dogs died on $1^{\text {st }}$ week of treatment and other one died on $3^{\text {rd }}$ week of treatment.

When compared between treatments of prednisolone ( $\mathrm{P}$ protocol) group and prednisolone combination with azathioprine group (AP Protocol) on $14^{\text {th }}$ and $28^{\text {th }}$ day after treatment the mean of $\mathrm{Hb}$ and $\mathrm{PCV}$ on $28^{\text {th }}$ day was significantly higher in the group of dogs treated with prednisolone. The means of remaining haematological and coagulation parameter were not significant as given in Table 4 and Table 5.

Table 4: Efficacy of different treatments on haemogram in idiopathic IMHA (Comparison in between two groups of treatment)

\begin{tabular}{lll}
\hline Parameters & $\begin{array}{l}\text { t-test value between } \\
\text { group (Day 14) }\end{array}$ & $\begin{array}{l}\text { t-test value between } \\
\text { group (Day 28) }\end{array}$ \\
\hline $\mathrm{Hb}(\mathrm{g} / \mathrm{dL})$ & $1.04^{\mathrm{NS}}$ & $2.41^{*}$ \\
$\mathrm{RBC}(\mathrm{mill} / \mu \mathrm{L})$ & $0.15^{\mathrm{NS}}$ & $0.42^{\mathrm{NS}}$ \\
$\mathrm{HCT}(\%)$ & $0.24^{\mathrm{NS}}$ & $0.64^{\mathrm{NS}}$ \\
$\mathrm{MCV}(\mathrm{fL})$ & $0.07^{\mathrm{NS}}$ & $0.32^{\mathrm{NS}}$ \\
$\mathrm{MCHC}(\mathrm{g} / \mathrm{dL})$ & $1.10^{\mathrm{NS}}$ & $0.19^{\mathrm{NS}}$ \\
$\mathrm{MCH}(\mathrm{pg})$ & $0.73^{\mathrm{NS}}$ & $0.01^{\mathrm{NS}}$ \\
\hline
\end{tabular}

* - Statistically significant $(\mathrm{P}>0.05) \mathrm{NS}$ - Non significant.

Table 5: Efficacy of different treatments on leucogram and coagulation profile in idiopathic IMHA (Comparison in between two groups of treatment)

\begin{tabular}{lll}
\hline Parameters & $\begin{array}{l}\text { t-test value between } \\
\text { group (Day 14) }\end{array}$ & $\begin{array}{l}\text { t-test value between } \\
\text { group (Day 28) }\end{array}$ \\
\hline WBC $(/ \mu \mathrm{L})$ & $0.30^{\mathrm{NS}}$ & $0.20^{\mathrm{NS}}$ \\
Neutrophil (\%) & $0.07^{\mathrm{NS}}$ & $0.02^{\mathrm{NS}}$ \\
Lymphocyte (\%) & $1.10^{\mathrm{NS}}$ & $0.38^{\mathrm{NS}}$ \\
Monocyte (\%) & $1.43^{\mathrm{NS}}$ & $0.84^{\mathrm{NS}}$ \\
Eosinophil (\%) & $0.57^{\mathrm{NS}}$ & $0.59^{\mathrm{NS}}$ \\
Platelet(10 $/ \mathrm{cmm})$ & $0.23^{\mathrm{NS}}$ & $0.35^{\mathrm{NS}}$ \\
PT $(\mathrm{sec})$ & $0.35^{\mathrm{NS}}$ & $0.28^{\mathrm{NS}}$ \\
APTT(sec) & $0.58^{\mathrm{NS}}$ & $0.63^{\mathrm{NS}}$ \\
\hline
\end{tabular}

NS - Non significant. 
In prednisolone and azathioprine combined treated group, there was a significant increase in the means of $\mathrm{Hb}, \mathrm{RBC}$ and PCV and platelet (Table 1, 2, 3, 4, 5 and 6). There was a significant reduction in mean of $\mathrm{WBC}$ and neutrophil and significant reduction in mean values of Blood urea nitrogen (BUN) after treatment. However, there was significant increase in means activity levels of ALP and ALT after treatment. Wang et al. (2013) reported adverse events including significantly increased ALT, vomiting and diarrhoea in dogs treated with azathioprine. Piek (2011) reported the lack of evidence of a beneficial effect of azathioprine over the use of prednisolone alone.

Table 6: Efficacy of different treatments on serum biochemistry in idiopathic IMHA (Comparison in between two groups of treatment)

\begin{tabular}{lll}
\hline Parameters & $\begin{array}{l}\text { t-test value between } \\
\text { group (Day 14) }\end{array}$ & $\begin{array}{l}\text { t-test value between } \\
\text { group (Day 28) }\end{array}$ \\
\hline BUN(mg/dL) & $2.78^{*}$ & $0.82^{\mathrm{NS}}$ \\
$\mathrm{Cr}(\mathrm{mg} / \mathrm{dL})$ & $0.89^{\mathrm{NS}}$ & $0.29^{\mathrm{NS}}$ \\
$\mathrm{TP}(\mathrm{g} / \mathrm{dL})$ & $1.22^{\mathrm{NS}}$ & $0.50^{\mathrm{NS}}$ \\
Albumin (g/dL) & $0.77^{\mathrm{NS}}$ & $0.81^{\mathrm{NS}}$ \\
Globulin (g/dL) & $0.80^{\mathrm{NS}}$ & $0.11^{\mathrm{NS}}$ \\
Albumin: Globulin & $0.96^{\mathrm{NS}}$ & $0.29^{\mathrm{NS}}$ \\
ALT (IU/L) & $5.20^{* *}$ & $0.77^{\mathrm{NS}}$ \\
ALP (IU/L) & $3.17^{* *}$ & $9.48^{* *}$ \\
T.bilirubin (IU/L) & $0.78^{\mathrm{NS}}$ & $0.77^{\mathrm{NS}}$ \\
D.bilirubin (IU/L) & $0.09^{\mathrm{NS}}$ & $1.30^{\mathrm{NS}}$ \\
\hline
\end{tabular}

Mean bearing same manuscript in the row do not differ significantly. ** - Statistically highly significant $(\mathrm{P} \leq 0.01) *$ - Statistically significant $(\mathrm{P}>0.05){ }^{\mathrm{NS}}-$ Non significant.

Mean of BUN on $14^{\text {th }}$ day was significantly higher in prednisolone treated group when compared to prednisolone + azathioprine group. Mean activity level of ALT was significantly higher in prednisolone + azathioprine group on $14^{\text {th }}$ day and $28^{\text {th }}$ day as compared to prednisolone treated group. Mean activity level of ALP was significantly higher in prednisolone combined with azathioprine group on $14^{\text {th }}$ day and $28^{\text {th }}$ day as compared to prednisolone treated group.

There was significant increase in ALP and ALT activities after immunosuppressive therapy. These changes might be due to steroid hepatopathy i.e. glucocorticoid induced increase in ALP isoenzyme activity and ALT enzyme activities in serum. The length of time required for serum ALT activity to increase is 9 to 23 days (Kaneko et al., 2008 ) which might be the reason for normal level on $0^{\text {th }}$ day and increased level on $28^{\text {th }}$ day.

Swann and Skelly (2013) studied the effect of different treatment regime (prednisolone and cyclospsorine, prednisolone and azathioprine and prednisolone alone) on survival of 42 dogs and observed a significant difference in the outcome between different treatments. The study also determined that the dogs with elevated serum urea and bilirubin had poor prognosis.

Piek (2011) reported the effect of azthioprine along with prednisolone in the treatment of primary IMHA and found that no statistical beneficial effect over standard predisolone treatment.

Azathioprine primarily suppresses lymphocyte activation and proliferation, reducing antibody production. Azathioprine also suppresses macrophage function which reduces inflammatory cytokine production and phagocytic efficiency.

The most common adverse effects of azathioprine therapy are GI disturbances and myelosuppression particularly in large dogs (Rinkardt and Kruth, 1996). Acute pancreatitis and cholestatic hepatopathy have been anecdotally reported in dogs receiving azathioprine (Houston and Taylor, 1991).

\section{Treatment outcome / response}

In the present study, mortality in idiopathic IMHA was 38.5 per cent. In idiopathic IMHA prednisolone and prednisolone + azathioprine treatment group mortality was 33.33 per cent and 42.9 respectively.

The mortality in the present study was 38.5 percent (primary IMHA), similar rate of mortality (20 to 33 per cent) was observed by Scott-Moncrieff et al. (2001). Mortality is mostly in the first 2 weeks of diagnosis (Piek, 2011). Similar observation was recorded in present study. Mortality in IMHA dogs might be due to thromboembolism (Scott - Moncrieff et al., 2001), tissue hypoxia and subsequent necrosis due to severe anaemia, liver and kidney failure, inflammation and DIC (Piek, 2011). Necropsy could not be performed in the present study due to the animal collapsed in the owner's house, 
the exact reason for death was not identified.

The overall mortality rate for primary canine IMHA varies from as low as 26 per cent to as high as 70 per cent (Weinkle et al., 2005). Despite this variability, most of the literature on IMHA agrees that the number-one cause of death is thromboembolic disease (Scott-Moncrieff et al., 2001 and Weinkle et al., 2005).

\section{CONCLUSION}

The anaemic dogs brought with clinical signs such as pale or icteric mucous membranes were screened for IMHA by saline agglutination and spherocyte count and confirmed by flow cytometry. The positive cases were further subjected to haematology, biochemistry, coagulation profile, MAT and polymerase chain reaction (PCR) for the diagnosis of underlying secondary causes like Babesia spp, Ehrlichia canis and Leptospira spp (secondary IMHA). Thirteen cases were idiopathic IMHA and Immunosuppressive therapy with prednisolone and prednisolone in combination with azathioprine and specific therapy of etiological agent with supportive therapy was used. Significant increase in $\mathrm{Hb}$, $\mathrm{PCV}, \mathrm{RBC}$ and thrombocyte count, significant decrease in leucocyte, neutrophil, monocyte and total protein and significant increase in ALT activity was recorded after therapy. Prednisolone was found to be effective in the management of canine idiopathic IMHA than prednisolone combined with azathioprine.

\section{COMPETING INTERESTS}

The authors declare that they have no competing interests.

\section{REFERENCES}

Balch, A. and Mackin, A. 2007. Canine immune- mediated hemolytic anemia: pathophiosology, clinical sign, and diagnosis. Compend. Cont. Educ. Vet., 29(4): 217-225.

Brunton, L.L., Lazo, S.J. and Parker, K.L. 2005. In: Goodman and Gilman's The Pharmacological basis of therapeutics. (11 ${ }^{\text {th }}$ Ed.). McGraw-hill, New York, pp. 201.

Day, M.J. 1996. Inheritance of serum autoantibody, reduced serum $\operatorname{IgA}$ and autoimmune disease in a canine breeding colony. Vet. Immunol. Immunopathol., 53(3-4): 207-219.

Dowling, P.M. 1995. Immunosuppressive drug therapy. Can. Vet. J., 36(12): 781-783.

Journal of Animal Research: v.10 n.3, June 2020
Fenty, R.K., DeLaforcade, A.M. Shaw, S.P. and O’Toole, T.E. 2011. Identification of hypercoagulability in dogs with primary immune-mediated hemolytic anemia by means of thromboelastography. J. Am. Vet. Med. Assoc., 238: 463-467.

Hodges, J. and Christopher, M.M. 2011. Diagnostic efficacy of using erythrocyte indices and polychromasia to identify regenerative anemia in dogs. J. Am. Vet. Med. Assoc., 238: $1452-1458$.

Houston, D.M. and Taylor, J.A. 1991. Acute pancreatitis and bone marrow suppression in a dog given azathioprine. Can. Vet. J., 32: 496-497.

Ishihara, M., Fujino, Y., Setoguchi, A., Takahashi, M., Nakashima, K., Ohno, K. and Tsujimoto, H. 2010. Evaluation of prognostic factors and establishment of a prognostic scoring system for canine primary immune-mediated hemolytic anemia. J. Vet. Med. Sci., 72(4): 465-470.

Jutkowitz, A., Kinns, J., Habing, A., Beal, M. 2013. CT angiography for detection of pulmonary thromboembolism and portal vein thrombosis in dogs with immune-mediated hemolytic anemia (IMHA). J. Vet. Emerg. Crit. Care., 23(S1): S15.

Kaneko, J.J., Harvey, J.W. and Bruss, M.L. 2008. In: Clinical biochemistry of domestic animals. ( $6^{\text {th }} \mathrm{Ed}$.). Elsevier, pp. 904.

Kledmanee, K., Suwanpakdee, S., Krajangwong, S., Chatsiriwech, J., Sukasai, P., Suwannachat, P., Sariya, L., Buddhirongawatr, R., Charoonrut, P. and Chaichoun, K. 2009. Development of multiplex polymerase chain reaction for detection of Ehrlichia canis, Babesia spp. and Hepatazoan canis in canine blood. Southeast Asian T. Med. Public Health., 40(1): 35-39.

Kucinskiene, G., Schuberth, H.J., Leibold, W.J. and Pieskus, J. 2005. Flow cytometric evaluation of bound $\operatorname{IgG}$ on erythrocytes of anaemic dogs. Vet. J., 169: 303-307.

Mason, N., Duval, D., Shofer, F.S. and Giger, U. 2003. Cyclophosphamide exerts no beneficial effect over prednisone alone in the initial treatment of acute immune mediated hemolytic anemia in dogs: a randomized controlled clinical trial. J. Vet. Intern. Med., 17(2): 206-212.

McCullough, S. 2003. Immune-mediated hemolytic anemia: understanding the nemesis. Vet. Clin. North. Am. Small Anim. Pract., 33: 1295-1315.

Mitchell, K. and Kruth, S. 2010. Immune-mediated hemolytic anemia and other regenerative anemias. In: Textbook of Veterinary Internal Medicine. $7^{\text {th }}$ edn. Eds S. J. Ettinger and E.C. Feldman, Saunders Elsevier, St. Louis, MO, USA. pp 761-772.

Morley, P., Mathes, M., Guth, A. and Dow, S. 2008. Antierythrocytes antibodies and disease associations in anemic and nonanemic dogs. J. Vet. Intern. Med., 22: 886-892. 
Piek, C.J., Van Spil, W.E., Junius, G. and Dekker, A. 2011. Lack of evidence of a beneficial effect of azathioprine in dogs treated with prednisolone for idiopathic immune-mediated haemolytic anaemia: a retrospective cohort study. BMC Vet. Res., 7: 15 .

Rajagopal, A.S., Abdul Basith, S., Gomathinayagam, S. and Dhinakarraj, G. 2009. Evaluation of PCR and IFAT in the Diagnosis of Canine Ehrlichiosis. J. App. Anim. Res., 35(2): 189-91.

Rang, H.P., M.M. Ritter, J.M. and Flower, R.J. 2007. In: Rang and Dales Pharmacology. (6 $6^{\text {th }}$ Ed.). Edinburgh, Churchill Livingstone, pp. 844.

Rinkardt, N.E. and Kruth, S.A. 1996. Azathioprine-induced bone marrow toxicity in four dogs. Can. Vet. J., 37: 612-613.

Scott-Moncrieff, J.C., Treadwell, N.G. and McCullough, S.M. 2001. Hemostatic abnormalities in dogs with primary immune-mediated hemolytic anemia. J. Am. Anim. Hosp. Assoc., 37: 220-227.

Swann, J.W. and Skelly, B.J. 2013. Systemic review of evidence relating to treatment of Immune Mediated Hemolytic anemia in dogs. J. Vet. Intern. Med., 27: 1-19.
Wang, A., Smith, J.R. and Creevy, K.E. 2013. Treatment of canine idiopathic immune mediated haemolytic anaemia with mycophenolate mofetil and glucocorticoids: 30 cases (2007 to 2011). J. Small. Anim. Pract., 54(8): 399-404.

Weinkle, T.K., Center, S.A., Randolph, J.F., Warner, K.L., Barr, S.C. and Erb, H.N. 2005. Evaluation of prognostic factors, survival rates, and treatment protocols for immune-mediated hemolytic anemia in dogs: 151 cases (1993-2002). J. Am. Vet. Med. Assoc., 226: 1869-1880.

Whelan, M.F., Toole, T.E.O., Chan, D.L., Rosanski, E.A., Armelle, M.A. Crawford, S.L. and Cotter, S.M. 2009. Use of immunoglobulin in addition to glucocorticoids for the initial treatment of dogs with immune-mediated hemolytic anemia. J. Vet. Emerg. Care. 19: 158-164.

Whitley, N.T. and Day, M.J. 2011. Immunomodulatory drugs and their application to the management of canine immunemediated disease. J. Small. Anim. Pract., 52(2): 70-85. 